\title{
Human population studies and the World Health Organization
}

\section{Soraya de Chadarevian (*)}

$\left.{ }^{*}\right) \quad$ orcid.org/0000-0002-4360-7203. Department of History and Institute for Society and Genetics, University of California Los Angeles. chadarevian@history.ucla.edu

Dynamis

[0211-9536] 2015; 35 (2): 359-388

http://dx.doi.org/10.4321/S0211-95362015000200005
Fecha de recepción: 4 de agosto de 2014

Fecha de aceptación: 23 de abril de 2015

SUMMARY: 1.-Introduction. 2.-WHO and the Cold War: some brief historical notes. 3.-Radiation, public health and the genetic study of human populations. 4.- «Vanishing» populations and the study of human evolution. 5.- International legitimization and standard procedures. 6.-Conclusions.

ABSTRACT: This essay draws attention to the role of the WHO in shaping research agendas in the biomedical sciences in the postwar era. It considers in particular the genetic studies of human populations that were pursued under the aegis of the WHO from the late 1950s to 1970s. The study provides insights into how human and medical genetics entered the agenda of the WHO. At the same time, the population studies become a focus for tracking changing notions of international relations, cooperation, and development and their impact on research in biology and medicine in the post-World War II era. After a brief discussion of the early history of the WHO and its position in Cold War politics, the essay considers the WHO program in radiation protection and heredity and how the genetic study of «vanishing» human populations and a world-wide genetic study of newborns fitted this broader agenda. It then considers in more detail the kind of support offered by the WHO for these projects. The essay highlights the role of single individuals in taking advantage of WHO support for pushing their research agendas while establishing a trend towards cooperative international projects in biology.

KEY WORDS: World Health Organization, human population studies, human heredity, «primitive people», Alan Stevenson, James V. Neel. 


\section{Introduction $(*)$}

In their introduction to a recent special issue on transnational science in the British Journal for the History of Science, Simone Turchetti, Néstor Herran and Soraya Boudia have encouraged historians of science to re-examine the role of international organizations in the production and circulation of knowledge in the postwar period. They suggest that such an approach may help to reflect on the contributions of a transnational approach in the history of science and the place of the sciences in a globalized world. The «new transnational history» they embrace focuses on the flow of people, goods and ideas across national borders ${ }^{1}$.

Taking up this challenge, this essay will take a closer look at the World Health Organization (WHO), one of the new international institutions established in the post WWII period, and its support for research projects in the biomedical sciences. The role of the WHO and other UN agencies in shaping scientific research agendas in the postwar era has only recently gained the attention of historians ${ }^{2}$. This essay will consider specifically the genetic studies of human populations that were pursued under the aegis of the WHO in the late 1950s to 1970s. The study will illuminate how human and medical genetics entered the agenda of the WHO. More generally, the essay aims to address the questions: what kind of research projects did the WHO support? Who profited and how? And how did international organizations like the WHO shape postwar science?

$\left(^{*}\right)$ I gratefully acknowledge support from the Wellcome Trust for a Small Research Grant, ref 099392/Z/12/Z in 2012-13.

1. Turchetti, Simone; Herran, Néstor; Boudia, Soraya. Introduction: Have we ever been «transnational»? Towards a history of science across and beyond borders. British Journal for the History of Science. 2012; 45: 319-336. The terms «international», «transnational», and «global» all point to a transgression of national boundaries and are sometimes used in an interchangeable manner or at least viewed as not exclusive; at other times they are conceptually distinguished. The terms can mean, and have meant, different things to different people. These meanings can best be unraveled historically. In this essay I do not introduce any definitional distinctions but rather attempt to follow actors' terms.

2. Petitjean, P.; Zharov, V.; Glaser, G. et al., eds. Sixty years of science at UNESCO, 1945-2005. Paris: UNESCO; 2006; Selcer, Perrin. Patterns of science. Developing science for a world community at UNESCO. Philadel phia: University of Pennsylvania; 2011; Radin, Joanna. Unfolding epidemiological stories. How the WHO made frozen blood a flexible resource for the future. Studies in History and Philosophy of the Biological and Biomedical Sciences. 2014; 47A: 62-73. 
After a brief discussion of the early history of the WHO and its position in Cold War politics, the essay considers the WHO program in radiation protection and heredity and how the genetic study of newborns and of «vanishing» human populations fitted this broader agenda. It will then consider in more detail the kind of support offered by the WHO for these investigations. Throughout, the study will highlight the role of single individuals in taking advantage of WHO support to push their research agendas while establishing a trend towards cooperative international projects in biology. The organization of these studies and the shaping of research questions in human population genetics become a focus for tracking changing notions of international relations, cooperation, and development and their impact on research in biology and medicine in the post-WWII era.

\section{WHO and the Cold War: some brief historical notes}

The WHO was founded as a specialized agency of the UN in 1946. The recommendation to establish a dedicated health agency came from Brazil and (pre-communist) China, and China and the UK were the first signatories. The constitution was ratified in 1948. It built on similar initiatives before the war, most notably the Health Organization of the League of Nations that ceased to exist with the foundation of the $\mathrm{UN}^{3}$. After the devastations and

3. On the contributions of the League of Nations Health Organization in establishing the notion of health as a global social and political issue and the principles of international health cooperation see Borowy, Iris. Coming to terms with world health. The League of Nations Health Organisation 1921-1946. Frankfurt am Main: Peter Lang; 2009. On the history of the long standing Pan American Health Organization (previously the Pan American Sanitary Bureau) that continued its work as the WHO Regional Office of the Americas see Cueto, Marcos. The value of health. A history of the Pan American Health Organization. Washington, DC: Pan American Health Organization; 2007. Cueto also provides details on the role of Brazil and China in proposing the WHO (p. 82-83). On the early history of the WHO see also the organization's internal history, World Health Organization. The first ten years of the World Health Organization. Geneva: World Health Organization; 1958 as well as Siddiqi, Javed. World health and world politics. The World Health Organization and the UN system. Columbus, SC: University of South Carolina Press; 1995; Brown, Theodore M.; Cueto, Marcos; Fee, Elizabeth. The World Health Organization and the transition from «international» to «global» health. In: Bashford, Alison, ed. Medicine at the border. Disease, globalization and security, 1850 to the present. Basingstoke; New York: Palgrave Macmillan; 2006, p. 76-94; Staples, Amy L. S. The birth of development. How the World Bank, Food and Agricultural Organization, and World Health Organization changed the world, 1945-1965. Kent: Kent State University Press; 
hardships of WWII the idea that every person had the right to achieve the highest possible level of health and that health was a fundamental factor to secure peace and security gained new impetus. Technologies developed during WWII, above all penicillin, DDT and new vaccines, were seen as providing powerful new tools to help achieve the aim of global public health. Considering this objective and the fact that «disease knows no frontiers» and that combatting it required global action, the founders intentionally called for a «world» rather than an «international» agency ${ }^{4}$.

Despite best intentions, the WHO did not escape Cold War tensions. A first political crisis for the agency ensued when, hardly had all nations signed up to the new constitution, the Soviet Union, followed by several Eastern bloc countries, withdrew their support. This was in 1949, but by the mid-1950s the Soviet Union reversed its course and became again an active member. Re-entry was suggested in 1955 and became operative in 1957. Other Eastern European countries followed suit. Indeed, the whole territory of the Soviet Union was considered part of the European region of the WHO, and Russian, next to English, French and Spanish, became a working language of the agency (figure 1). The People's Republic of China, founded in 1949, only joined the UN and the WHO in 1972, taking the place of Taiwan (officially the Republic of China) who had maintained membership throughout the preceding decades ${ }^{5}$. This clearly indicates that the WHO was

2006; Amrith, Sunil S. Decolonizing international health. India and Southeast Asia, 1930-1965. Basingstoke; New York: Palgrave Macmillan; 2006. On the rise of international governmental and non-governmental organizations as a defining feature of the twentieth century see Iriye, Akira. Global community. The role of international organizations in the making of the contemporary world. Berkeley: University of California Press; 2002. According to Iriye the post-WWII period in particular saw the formation of a «new internationalism» that defied Cold War divisions.

4. Chronicle of the World Health Organization, volume 1. Development and Constitution of the W.H.O. New York and Geneva: World Health Organization Interim Commission; 1947 (13). See also Farley, John. Brock Chisholm, the World Health Organization, and the Cold War. Vancouver: University of British Columbia Press; 2008 (p. 2). Commenting on the fact that the terms «international», «intergovernmental» and «global» do not need to exclude each other, historians have pointed out that the WHO can be viewed as an «intergovernmental agency that plays international roles and exercises international functions-with the aim of improving global health». Brown; Cueto; Fee, n. 3, p. 77.

5. Note, however, that the 1958 map reproduced in figure 1 lists the whole territory of the People's Republic of China as belonging to the Regional Office of the Western Pacific. Regarding the (temporary) withdrawal of the Soviet Union and the Eastern European countries, the WHO argued that the constitution contained no provision for such a step and continued to list the countries as members. Manela, Ezra. Globalizing the great society. Lyndon Johnson and 
fully exposed to but also defied Cold War tensions. As a recent biography of the first Director General of the WHO, the Canadian Brock Chisholm, stated: «During Chisholm's years in office, the Cold War and its politics were always palpable» ${ }^{6}$. This was also noticeable in the kind of public health interventions the WHO embraced. As the same biographer noted «[...] Cold War realities more or less demanded that 'hearts and minds' be captured by quick, Western-directed solutions to medical problems rather than by the slow grind of social and economic improvements», although the latter approach also had its advocates within the $\mathrm{WHO}^{7}$.

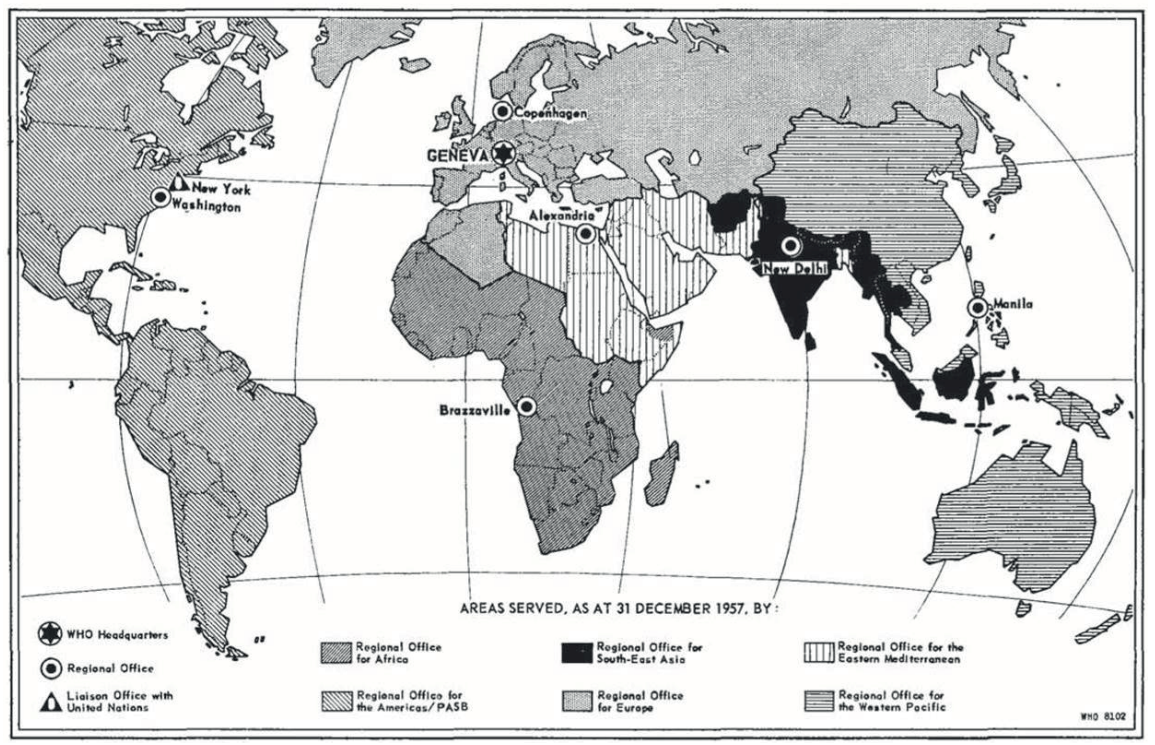

Figure 1: WHO regional offices and the areas they served (1958). Source: The first ten years of the World Health Organization. Geneva: World Health Organization; 1958. Courtesy of WHO.

the pursuit of smallpox eradication. In: Gavin, Francis; Lawrence, Mark Atwood, eds. Beyond the Cold War. Lyndon Johnson and the new global challenges of the 1960s. Oxford: Oxford University Press; 2014, p. 165-181 (178, note 5). Perhaps a similar explanation holds for the continued inclusion of the territory of the People's Republic of China in WHO maps.

6. Farley, n. 4, p. 3.

7. Farley, n. 4, p. 3. 
It would, nevertheless, be an undue simplification to see the WHO as a mere extension of Western interests or US imperial ambitions. The relation of the US to the UN organization was conflicted from the beginning, and even if US interests might have dominated the organization in the early years, the situation changed with the re-entry of the Soviet Union and the adoption, in the 1970s, of the primary health care approach to global health. This new policy was inspired by the model of the «barefoot doctors» in China but was championed by the Soviet Union ${ }^{8}$. The policy change was prefigured earlier with the growing difficulties encountered by the malaria eradication campaign that embodied widely shared Western ideas of development and public health interventions ${ }^{9}$. Thus, especially from the 1960s onwards, the WHO became a forum for the elaboration of alternative models of development that balanced Western ideals and ambitions with the changing needs and demands of decolonizing and emerging nations in an ideologically divided world.

How these policies played out in concrete situations was another matter. US historian Erez Manela has presented the small pox eradication campaign launched in the 1960s at the height of the Vietnam conflict as an example of an intervention that transgressed Cold War divisions. In fact, Manela argues that the «scant interest of the political classes» in both power blocks in the eradication campaign was «likely one of the reasons for its success, as it allowed the motley crew of eradicators and health officials to operate largely as if there was no Cold War» ${ }^{10}$. Medical historian Sanjay Bhattacharya focussed on the same campaign to argue against a monolithic account of the WHO that overlooks the role of the institution's regional offices and of local governments in shaping WHO policies ${ }^{11}$.

If in some WHO campaigns Cold War tensions could be circumvented, other projects were a direct response to situations created by the Cold War

8. On the initial dominance of US interest and the subsequent policy changes, Siddiqi, n. 3; Lee, Sung. WHO and the developing world. The contest for ideology. In: Cunningham, Andrew; Andrews, Bridie, eds. Western medicine as contested knowledge. Manchester; New York: Manchester University Press; 1997, p. 24-45; Brown; Cueto; Fee, n. 3, p. 76-94.

9. Brown; Cueto; Fee, n. 3, p. 76-94. On the embracement of Western ideas of development by decolonising nations see Lee, n. 8, p. 24-45. On the malaria eradication campaign see also Litsios, Socrates. Malaria control, the Cold War, and the postwar reorganization of international assistance. Medical Anthropology. Cross-Cultural Studies in Health and IIIness. 1997; 17: 255278; Staples, n. 3.

10. Manela, n. 5, p. 165-181 (p. 176).

11. Bhattacharya, Sanjoy. Expunging variola. The control and eradication of smallpox in India, 1947-1977. London: Sangam Books; 2006. 
arms race. This was the case with the WHO program in human heredity that developed out of the organization's interest in the effects of nuclear radiation on the health of human populations ${ }^{12}$.

\section{Radiation, public health and the genetic study of human populations}

The interest of the WHO in the public health implications of atomic radiation started in the mid-1950s, at a time of increasing political and public concerns about global radioactive fallout from nuclear bomb testing and the simultaneous expansion of programs for the "peaceful» (read commercial) uses of atomic energy ${ }^{13}$. The global effects of radioactive fallout that transcended national boundaries and iron curtain divisions were made graphically clear by maps like the one reproduced here that recorded the worldwide distribution of radioactive strontium in fallout (figure 2). The map showed that highest strontium concentrations were recorded in the northern hemisphere. Contamination was by no means limited to areas around testing sites in North America, Siberia, or the South Pacific, but rather appeared in bands of equal concentration that spanned the globe. Strontium accumulates in bones, especially in children, and was known to produce cancer. In view of the accumulation of such data, in 1956 the World Health Assembly recognized protection against radiation as a global public health issue, and designated it as a new area of responsibility for the $\mathrm{WHO}^{14}$.

Other international organizations also claimed responsibility for various aspects of the development of civilian uses of atomic energy, including training, surveillance and protection against the effects of radiation. The growing

12. World Health Organization. The second ten years of the World Health Organization, 1958-1967. Geneva: World Health Organization; 1968; World Health Organization, n. 3, p. 293-294; Effect of radiation on human heredity. Report of a study group convened by WHO together with papers presented by various members of the group. Geneva: World Health Organization; 1957.

13. For a historical reconstruction of the fallout debate in the US context see Hacker, Barton C. Elements of controversy. The Atomic Energy Commission and radiation safety in nuclear weapons testing, 1947-1974. Berkeley: University of California Press; 1994. On the polyvalent significance of the American Atoms for Peace program see Krige, John. Atoms for peace, scientific internationalism, and scientific intelligence. In: Krige, John; Barth, Kai-Henrik, eds. Global knowledge power. Science and technology in international affairs. Osiris 2006; 21: 161-181; Creager, Angela N. H. Life atomic. A history of radioisotopes in science and medicine. Chicago: Chicago University Press; 2013, p. 137-142.

14. World Health Organization, n. 3, p. 291. 


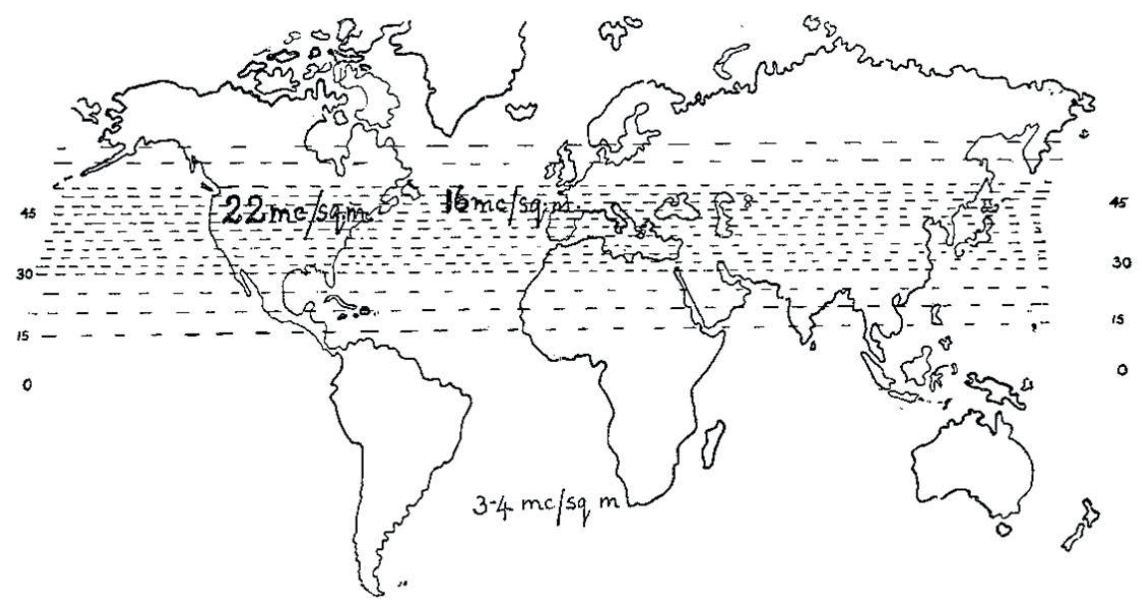

Figure 2: World-wide distribution of strontium 90 in fallout, showing highest concentration in the northern latitudes (1956). Source: Pirie, Antoinette. Fall out. Radiation hazards from nuclear explosions. London: MacGibbon \& Kee; 1958, p. 2. Copyright: Harper Collins (UK).

list of institutions included the International Commission on Radiological Protection (ICRP), a non-governmental international organization whose beginnings went back to the 1920s; the United Nations Scientific Committee on the Effects of Atomic Radiation (UNSCEAR), founded in 1955, that regularly issued reports on radiation risks; the International Atomic Energy Agency (IAEA), set up in 1957 as an independent agency with seat in Vienna to foster international cooperation in the peaceful and safe uses of nuclear technologies, that nevertheless reported to both the United Nations General Assembly and the Security Council; and UNESCO that positioned itself to take responsibility for all educational aspects concerning atomic energy. All these institutions took it for granted that atomic energy as a technology was there to stay. Military aspects were explicitly excluded from all deliberations. It is in this busy field of overlapping responsibilities and competencies of various institutions that the WHO carved out a space for itself in the field of radiation protection. Competition between agencies was managed through bi-lateral agreements, as exemplified by the agreement, signed in 1959, between the WHO and the IAEA ${ }^{15}$.

15. In the wake of the nuclear disasters in Chernobyl and Fukushima the WHO was criticized for its continuing agreement with the IAEA that seemed to limit its independence in investigating 
The WHO was still developing its program in respect to health risks and radiation when the Government of Denmark, in cooperation with other North European countries, suggested that the WHO could only meet its new responsibility if it also considered the effects of radiation on human heredity ${ }^{16}$. Copenhagen was to host the First International Congress of Human Genetics in 1956 and it was in Copenhagen, directly following the congress, that the WHO Study Group on the Effect of Radiation on Human Heredity first met. Perhaps only coincidentally, Copenhagen was also the headquarter of the WHO Regional Office for Europe. In a position paper on «The general problem of protection against radiation from the public health point of view», presented at the UN Conference on the Peaceful Uses of Atomic Energy in Geneva in 1955, the WHO had already outlined the need for «a world-wide scientific study of radiation induced genetic effects from the standpoint of the world population» ${ }^{17}$. However, it was only in Copenhagen that such a program was discussed in any detail.

In its report, published in 1957, the Study Group, composed of twenty prominent geneticists from Denmark, France, Germany, Sweden, the UK, Canada, the USA, Brazil and India, several of them working in atomic energy establishments, made a strong case for the need of a sustained research effort in the field of genetics ${ }^{18}$. The report stated:

«If there is to be a climate of public opinion favourable to the development of nuclear energy, the people must be assured that investigations essential for their future health and welfare and that of their children will be undertaken on an adequate scale. This will require recognition by governments that very

radiation hazards. Sascha Gabizon (Executive Director, Women in Europe for a Common Future) to Dr Maria Neira (Director, Public Health and Environment, WHO), 6 Apr 2010. Available online: http://www.wecf.eu/download/2010/04/letterlAEA-WHO.pdf; accessed 29 Dec 2014.

16. World Health Organization, n. 3, p. 293; Human and medical genetics submitted by the delegations of Denmark, Finland, Iceland, Norway and Sweden. Eighth World Health Assembly, A8/P\&B/1, 18 May 1955. Available online: http://apps.who.int/iris/bitstream/10665/104144/1/ WHA8_PB-17_eng.pdf; accessed 29 December 2014.

17. World Health Organization. The general problem of protection against radiation from the public health point of view. Abstract of a paper presented at the UN conference on Peaceful Uses of Atomic Energy in Geneva in 1955; copy of document at UNESCO Archives, Paris; box 415/620.992.539.16.

18. Conspicuously absent were representatives from the Eastern European countries and the Soviet Union. 
substantial financial provision must be made for genetic and other biological investigations essential to an understanding of the effects of radiation on man» ${ }^{19}$.

In many respects the study group re-iterated the conclusions of two previous, widely noted reports on the biological effects of nuclear radiation, one published by the Medical Research Council (MRC) and presented to the British Parliament, the other one prepared by the US National Academy of Sciences ${ }^{20}$. Yet the WHO study group provided the strongest endorsement for genetic research so far and emphasized the need for all governments to act. Although the report refrained from recommending specific projects, it nonetheless enumerated a long series of issues that in the view of the study group required urgent attention. The list included the study of spontaneous and artificially induced mutations; of mutations produced by radiation in somatic cells and its role in cancerogenesis; the protection against mutagenic agents; better techniques for identifying mutations; the manner of gene action; selective factors in populations (especially in human populations); twin studies; the frequency of diseases with a genetic component, for instance haemoglobinopathies; the study of populations of special genetic interest, including «primitive» populations, isolated by geography or culture; the genetic mapping of human genes; cytochemistry and cytogenetics; and statistical methods for population studies ${ }^{21}$. Several of these issues directly addressed the genetic effects of radiation, others related to a more general understanding of genetic principles and of the genetic structure of human populations. Such general knowledge was regarded as essential to assess the risk of radiation damage. Genetic effects were understood to cover not only mutations in the germ cells that were transmitted to future generations but also mutational effects in somatic cells and their role in

\footnotetext{
19. Effect of radiation, n. 12, p. 15.

20. Medical Research Council. Hazards to man of nuclear and allied radiations. London: Her Majesty's Stationery Office; 1956 (Cmd 9780); The biological effects of atomic radiation. A report to the public. Washington, D.C.: National Academy of Sciences - National Research Council; 1956. On the history of the two reports, de Chadarevian, Soraya. Mice and the reactor. The "genetic experiment» in 1950s Britain. Journal of the History of Biology. 2006; 39: 707-735; Beatty, John. Masking disagreement among experts. Episteme. 2006; 3: 52-67; Hamblin, Jacob Darwin. «A dispassionate and objective effort». Negotiating the first study on the biological effects of atomic radiation. Journal of the History of Biology. 2007; 40: 147-177.

21. Effect of radiation, n. 12, p. 15-18
} 
the development of cancer ${ }^{22}$. Besides the effects from nuclear fallout, the growing use of nuclear radiation techniques in the clinic and in industrial contexts also raised public health concerns. Finally, there was an increasing realization that -independently from radiation hazards - diseases with a genetic component were widespread in human populations, strengthening the case for human heredity as a public health issue.

Research support was not a priority for the WHO. Nevertheless, in the mid-1950s the decision was taken to strengthen the program in medical research. This decision was followed by an «enthusiastic» support for research in human heredity and by its designation as a «high-priority field $»^{23}$. This decision was taken although there was no geneticist on the medical research committee. As was pointed out at a later occasion, «genetic considerations add a new dimension to public health work: a concern not only for the health and well-being of persons now living, but also for the genetic endowment of generations yet to come» ${ }^{24}$. The WHO here responded to widespread concerns about the genetic future of human kind.

Immediately following the decision of the WHO to engage in genetic research, and on the solicitation of the WHO Director of Research Erwin Kohn, Alan Stevenson, the Director of the newly established MRC Population Genetics Research Unit in Oxford, got in touch with American geneticist James V. Neel. In his letter Stevenson solicited a meeting to discuss «the scope of work which W.H.O. could usefully do in stimulating and promoting research in human genetics» and to possibly suggest some concrete proposals ${ }^{25}$. Neel had made his name as chief scientist of the Atomic Bomb Casualty Commission and its genetic project in Japan and was now putting his energy in building up a Department of Human Genetics at the University of Michigan in Ann Arbor, one of the first of its kind in the United States. His aim was to place the study of human genetics on

22. Creager, Angela, Radiation, cancer, and mutation in the atomic age. Historical Studies in the Natural Sciences. 2015; 45 (1): 14-48.

23. Dobson, R. Lowry to Frota-Pessoa, Oswaldo, 10 May 1960; Kohn, Erwin (WHO) to Florkin, Marcel (Liège), 20 October 1959. WHO Archives, Geneva. File G3-370-2. Plan for a medical research program related to human genetics (1955-1966).

24. WHO Expert Committee on Human Genetics. Human genetics and public health. Second report of the WHO Expert Committee on Human Genetics. World Health Organization Technical Report Series, no. 282, 36. Geneva: World Health Organization; 1964. Also quoted in World Health Organization, 1968, n. 12, p. 230.

25. Stevenson, Alan to Neel, James V., 25 February 1959. WHO Archives. File G 3/370/2. Plan for a medical research program related to human genetics. 
a sound scientific basis and steer it away from eugenic concerns ${ }^{26}$. The informal meeting took place in Ann Arbor a few weeks later. William J. Schull, Neel's collaborator at Ann Arbor, and John A. Fraser Roberts, the Director of the MRC Clinical Genetics Research Unit at the Hospital for Sick Children at Great Ormond Street in London, also participated. The group produced a ten-page report, summarizing their deliberations. It highlighted a need for training, the exchange of scientific information, a standardized nomenclature in human genetics, and the expansion of the collection of vital statistics data for genetic research. Furthermore, the group suggested two concrete projects that in their view responded to urgent research needs and could profit significantly from WHO support as they both relied on the «cooperative efforts of several countries». One was a comparative study of births (including stillbirths and infant death) in maternity hospitals in various countries around the world; the second one a study of populations of «unusual genetic interest», including especially «primitive groups» and «isolated» populations ${ }^{27}$. Here and elsewhere «primitive people» were defined as people living in small, isolated societies, characterized by simple economies based on hunting and gathering, simple pastoral life or digging-stick and hoe-type of agricultural technologies ${ }^{28}$.

26. On Neel's work with the Atomic Bomb Casualty Commission and the sensitive scientific, diplomatic and political dimensions of the project, Beatty, John. Genetics in the atomic age. The Atomic Bomb Casualty Commission, 1947-1956. In: Benson, Keith B.; Maienschein, Jane; Rainiger, Ronald, eds. The expansion of American biology. New Brunswick: Rutgers University Press; 1991, p. 284-324; Lindee, M. Susan. Suffering made real. American science and the survivors at Hiroshima. Chicago: Chicago University Press; 1994. On Neel's career more generally see his autobiography, Neel, James V. Physician to the gene pool. Genetic lessons and other stories. New York: John Wiley \& Sons; 1994. For the broader context of human and medical genetics in twentieth-century America, Comfort, Nathaniel. The science of human perfection. How genes became the heart of American medicine. London: Yale University Press; 2012.

27. Neel, James V; Fraser Roberts, John Alexander; Schull, William J.; Stevenson, Alan C. Possible roles of the World Health Organization in research in human genetics. Report of a meeting of Drs. Neel, Fraser Roberts, Schull, and Stevenson in the Department of Human Genetics, University of Michigan, from April 28th to April 30th, 1959. WHO Archives. File G 3/370/2. Plan for a medical research program related to human genetics.

28. Schull, William J. Some considerations on the design of genetic surveys. In: Baker, Paul T.; Weiner, Joseph Sidney, eds. The biology of human adaptability. Oxford: Clarendon Press; 1966, p. 26. In his autobiography, published in 1994, Neel remarked that, although «primitive» was «the accepted term» for such populations he had «slowly come to feel not only that it is unduly pejorative» but also that he had «increasing difficulty defining the societal dividing line between primitive and nonprimitive behavior». Here he referred to the recent atrocities committed during the civil war in the former Yugoslavia. He chose to use the term «tribal» 
While the comparative birth study would provide important insights into the distributions of various mutations and malformations and on the respective role of genes and environment in disease formation, the study of «unusual» populations would provide information on natural selection and on the relative role of biological and social factors in mating patterns, fertility, morbidity and life expectancy, among others. The authors of the report were careful in pointing out that the program proposed «cannot be expected to yield immediate and spectacular results of obvious benefit to large groups of people» and that research in human genetics «moves slowly and requires long-term support» ${ }^{29}$.

The WHO Advisory Committee on Medical Research «warmly» received the report and used it as a basis to set its priorities. Indeed it gave its stamp of approval to the comparative study of newborns, the genetic study of populations exposed to high natural radiation and of «unusual populations» as well as to some training courses, notably in human tissue culture and chromosome preparation techniques. These techniques had recently produced significant results by helping to unravel the chromosomal basis of Down's syndrome and other complex congenital conditions ${ }^{30}$.

Shortly following the decision, Stevenson, who had already conducted a smaller such study in Northern Ireland, took responsibility for the newborn study, while Neel spearheaded the study of «unusual populations» ${ }^{31}$. If we ask why Stevenson and Neel rather than other geneticists took the lead

groups instead. Neel, n. 26, p. 120. In this essay I will follow actors' terms when referring to historical sources, but will refer to indigenous people otherwise. On diverging notions of «primitive populations» and their value for anthropological research see also Santos, Ricardo Ventura; Lindee, Susan; De Souza, Vanderlei Sebastião. Varieties of the primitive. Human biological diversity studies in Cold War Brazil (1962-1970). American Anthropologist. 2014; 116: 723-735.

29. Neel; Fraser Roberts; Schull; Stevenson, n. 27.

30. Dobson, R. Lowry to Stevenson, Alan, 15 November 1959; Dobson, R. Lowry to Neel, James V., 16 November 1959. WHO Archives. File G 3/370/2. Plan for a medical research program related to human genetics. On the use of human karyotyping techniques in population studies, de Chadarevian, Soraya. Chromosome surveys of human populations. Between epidemiology and anthropology. Studies in the History and Philosophy of Biological and Biomedical Sciences. 2014; 47: 87-96.

31. As head of the Department of Social and Preventive Medicine at Queen's University in Belfast Stevenson had initiated a study to establish the frequency of single gene disorders in the population of Northern Ireland as a way to assess the burden of genetic disease and devise ways to alleviate it. He continued to study the genetic structure of human populations by establishing the distribution pattern of medically important traits in his new post in Oxford. 
role in this consultation process, the answer seems to lie in pre-existing personal connections with the Director of Medical Research, Erwin Kohn, and with R. Lowry Dobson, Chief Medical Officer for Radiation and Isotopes at the WHO, and an interest in and familiarity with international projects and bureaucratic superstructures for the support of collaborative research. Neel's experience with the Atomic Bomb Casualty Commission, officially a collaborative project between the Japanese and the US government, was especially relevant here. However, the WHO officers responsible for its research agenda consulted widely. At one point or another most of the wellknown geneticists at the time would have been in contact with the WHO, by correspondence or by participating in one of the expert committees or scientific conferences.

WHO officers quickly moved to affirm that the interest of the institution in human genetics and its relation to disease was «by no means confined to radiation genetics», but rather covered the broad field of human genetics ${ }^{32}$. Besides the projects already mentioned, and partly intersecting with them, the study of the distribution, treatment and prevention of heritable hematological diseases, including thalassemias, hemoglobinopathies and glucose-6-phosphate dehydrogenase, also became a major area of activity. Together these diseases were considered to «represent a major public health problem» ${ }^{33}$. In addition, genetic considerations became part of many other WHO projects, including work on mental health, cardiovascular diseases, maternal and child health and reproductive medicine.

Stevenson swiftly proceeded to draw up lists of hospitals with large maternity departments in different parts of the world that could be enrolled in the study; draft circular letters to national authorities and responsible ministers to ask for collaboration and permission to proceed with the study; draw up exact procedures for data collection, and work out the details of the study with the WHO. It was agreed that each collaborating hospital should record the details of 10000 consecutive births, that data

32. R. Lowry Dobson to Frota-Pessoa, Oswaldo (São Paulo), 10 May 1960. WHO Archives. File G3370-2. Plan for a medical research program related to human genetics (1955-1966). The full quote reads: «WHO is greatly interested in human genetics.... This interest I am sure you realise, is by no means confined to radiation genetics although this aspect has, because of the historical development of the WHO program, received special attention so far. On the contrary, the organization's interest is the broad field of human genetics, of which radiation genetics is a small, albeit significant part».

33. World Health Organization, n. 12, p. 231. 
collection was to be standardized and that the data would be assembled and processed in the statistical section of Stevenson's unit at Oxford that was well equipped for the task.

The results published five years later in a special supplement of the Bulletin of the World Health Organization presented the data of more than 420000 pregnancies (including over 5000 sets of twins) collected in 24 hospitals in 16 different countries, including Australia, Brazil, Chile, Columbia, Czechoslovakia, Egypt, Hong Kong, India, Malaysia, Mexico, Northern Ireland, Panama, Philippines, South Africa, Spain and Yugoslavia ${ }^{34}$. The authors distilled some significant findings from the data as, for instance, the large contribution of neural tube defects to spontaneous abortions and the strong association of consanguinity of the parents with high stillbirth and early death rates of infants. These associations were consistently found in all data sets although the incidences varied in various hospitals and regional areas. Mostly, however, the 120-page publication - supplemented by a 400page companion booklet, available on request, containing the data tables of each hospital- was a compilation of data that invited further analysis. The authors presented it as the largest available data set available for the study of congenital malformations. They suggested various questions to be followed up in specific hospitals, but the initiative was left to others ${ }^{35}$.

Two years later Stevenson chaired an expert meeting on «Genetic factors in congenital malformations» in Geneva that laid the methodological basis for further studies in this field ${ }^{36}$. His involvement with the WHO seems to

34. Stevenson, Alan C.; Johnston, Harold A; Stewart, M. I. Patricia; Golding, Douglas R. Congenital malformations. A report of a study of a series of consecutive births in 24 centres. Bulletin of the World Health Organization. 1966; 34: Supplement.

35. Focussing on the career of the Mexican physician Salvador Armendares Sagrera, Ana Barahona has provided some insight into the impact of Stevenson's project on the development of medical genetics in Mexico. The young Armendares met Stevenson when he came to Mexico to present the international project on congenital malformations. Armendares later spent two years with Stevenson in Oxford as a doctoral student. On his return to Mexico in 1966, he became instrumental in building up clinical cytogenetics in his country. With his colleagues and the newly acquired tools he followed up on some of the findings of the international project, especially regarding the unusually high numbers of newborns with Down syndrome that the data showed for Mexico. Barahona, Ana. Medical genetics in Mexico. The origins of cytogenetics and the health care system. Historical Studies in the Natural Sciences. 2015; 45 (1): 147-173. The impact of the WHO study in other countries and the development of an integrated program in medical genetics at the WHO will require further investigation.

36. Genetic factors in congenital malformations. Report of a WHO Scientific Group. World Health Organization Technical Report Series No. 438. Geneva: World Health Organization; 1970. 
have ended there. His unit in Oxford that had started with a stellar team of young human geneticists had soon suffered an exodus and was heading for closure on his retirement in the early $1970 \mathrm{~s}^{37}$. In contrast, Neel was to emerge as a key protagonist of the WHO program in genetic research, with the agency offering him the right stage for his expanding research agenda.

\section{4. «Vanishing» populations and the study of human evolution}

It is not clear if Neel already had a specific project in mind when he and his colleagues suggested the study of «unusual genetic populations» as a possible area of interest for the WHO. Yet soon his study of the Xavante Indians in Brazil served as a pilot project for a broader engagement of the WHO with the study of "primitive populations».

Before settling on a study in Brazil, Neel tried to enlist the support of the WHO for an ambitious plan to survey the presence of abnormal haemoglobins and their impact on morbidity and mortality in Western parts of Africa. Neel planned to reach villages «as nearly untouched by the medical progress of the last 100 years as possible». Although the primary aim was to study the impact of abnormal hemoglobins, in effect it was «an effort to come to grips with the problem of natural selection in primitive communities, a problem of great importance in human genetics today» ${ }^{38}$. Studying these communities was urgent - a point Neel stressed over and over again - as they were about to disappear, hence also the term of «vanishing populations», a trope first introduced by the Swiss zoologist, ethnographer and nature conservancy advocate Paul Sarasin in the 1910s. Whereas in an evolutionary framework, so much en vogue at the turn of the century, the extinction of «primitive people» would seem inevitable, Sarasin had argued that «primitive people» (or Naturvölker) needed to be protected because of their scientific value ${ }^{39}$. Studying the genetic structure of populations

37. A frank account of the situation at the Oxford unit is provided in the manuscript note by George Robert Fraser, Account of life with Marco Fraccaro in the Medical Research Council Population Genetics Research Unit, 1960-1961. 2008. Wellcome Library, London. File PP/ GRF/A.38, box 4 .

38. Neel, Alan V. to Candau, Marcolino Gomes (Director General WHO), 19 Feb 1960. WHO Archives. File G3-370-2. Plan for a medical research program related to human genetics (1955-1966).

39. De Bont, Raf. «Primitives» and protected areas. International conservation and the «naturalization» of indigenous people, ca. 1910-1975. Journal of the History of Ideas. 2015; 76: 215-236. I thank Raf de Bont for sharing an early version of the paper. 
that were considered as living in conditions as close as possible to those that characterized most of the evolutionary history of humans was all the more important at a moment in history when human populations around the world were exposed to new genetic risks. Understanding the impact of these changes required extended knowledge of the selective pressures to which humans were exposed during their history. Hence, studying the past as preserved in the few surviving populations still untouched by modern civilization provided an essential key to understanding the present and future of human heredity ${ }^{40}$.

A year later Neel was in Brazil to attend a WHO meeting on the studies of areas of high natural radiation. On this first trip he did not even find time to visit «Salzano and his Indians» because of pressures at his home institution. After gaining a $\mathrm{PhD}$ in São Paulo with a study on drosophila genetics, Francisco M. Salzano had spent a year as a postdoctoral fellow in Neel's department in Ann Arbor in 1956. During this time he re-directed his interests from drosophila genetics to human genetics. On his return to Brazil he embarked on an extended genetic study of Indian tribes in the Rio Grande do Sul area. Yet Neel intended to make good on his omission. Only a few weeks after his visit, he wrote an upbeat letter to the «Members of the Human Genetics Commission of Brazil», some of whom he had met on his brief visit, laying out the plan for a return trip and for a pilot study of 4-5 weeks on «certain aspects of the population genetics of the Indians» ${ }^{41}$.

«I am sure that I do not have to emphasize to a group such as you the need for studies on the population genetics and population dynamics of primitive groups», he told his Brazilian colleagues. «I am also sure that I do not have to emphasize to you the need for such studies right now, since with the rapid spread of civilization many of the remaining opportunities will vanish during our lifetimes». More specifically the study would aim to collect pedigree data for complete tribes; blood, serum and saliva specimens;

40. Neel, James $\mathrm{V}$. The study of natural selection in primitive and civilized human populations. Human Biology. 1958; 30: 43-72; Ventura Santos, Ricardo. Indigenous people, postcolonial contexts and genomic research in the late twentieth century. A view from Amazonia (19602000). Critique of Anthropology. 2002; 22: 81-104; Lindee, M. Susan. Voices of the dead. James Neel's Amerindian studies. In: Salzano, Francisco M.; Hurtado, A. Magdalena, eds. Lost paradises and the ethics of research and publication. Oxford: Oxford University Press; 2004, p. 27-48.

41. Neel, James V. to members of the Human Genetic Commission in Brazil, 27 Dec 1961. WHO Archives. File G 3/445/3. Human genetics - study of primitive tribes in Brazil. 
physical measurements; and data on disease pressure and consanguinity. Will we get «the cooperation of these Indians in such tests, using, of course, for visual testing the charts of illiterates?» he inquired somewhat fearfully. He suggested that the pilot would not compete with Salzano's study but rather would complement it; that WHO support might be forthcoming; and that the study could serve as a model for studies to be carried out in other parts of the world. Neel hoped that his «considerable experience in setting up collaborative projects» as well as his background in population genetics and field work would prove useful. Nevertheless, he regarded the proposed study as «primarily a Brazilian study» with himself being «only one of several collaborators, each with a specific contribution to make». He assured his interlocutors that he did not have in mind «rushing in to scoop up some data and return back home», nor did he foresee to assume senior authorship on any possible publication. As far as possible the analysis of the samples should be performed in Brazil, although his Ann Arbor laboratory was available as a backup and for specialized tests ${ }^{42}$.

In a parallel letter to the WHO Neel asked for official recognition and support for the project. Once more he stressed the urgency of the study and highlighted the unique opportunities that existed in Brazil for such a project given the «considerable concentration» in the country "of some of the most primitive tribes yet known» and the local pool of interested and talented young human geneticists, several of whom had been postdoctoral students in Ann Arbor. Throughout, Neel highlighted the complexity and scale of the endeavour ${ }^{43}$.

Eventually the team would comprise Salzano, a Brazilian hematologist, a German physical anthropologist visiting Brazil, a Harvard cultural anthropologist, and Neel himself. Yet even before the planned fieldwork got under way, Neel threw himself into the organization of what he presented to the WHO officials as a «milestone» conference on «Population Genetics of Primitive People». The agenda included a discussion of the concepts of population genetics; of the rationale and need for studies of «primitive populations»; of standard protocols for such studies; and a survey of populations suitable for study. The conference was to gather anthropologists, demographers and genetists as comprehensive population studies human

\footnotetext{
42. All quotes from Neel, n. 41.

43. Neel, James V. to Dobson, R. Lowry 27 December 1961. WHO Archives. File G 3/445/3. Human genetics - study of primitive tribes in Brazil.
} 
population that responded to scientific criteria required the formation of interdisciplinary research teams. Whenever possible the researchers were to be drawn from countries where the target populations occurred. The final goal of the meeting was to produce a «standard reference manual» that could serve as a basis for future studies ${ }^{44}$.

Both the manual and the results of the field study in Brazil, a «monstrous 88 -page paper», were published two years later ${ }^{45}$. Together they provided a field guide for studies of «primitive» populations, a model study, and a strong call to action. The manual, in particular, called on the WHO to immediately start preliminary studies of surviving «primitive» populations and to explore ways of assisting both pilot and full-scale studies extending to several years ${ }^{46}$.

In the following years the WHO supported studies of the Babinga pygmies of Central Africa led by the Italian population geneticist Luca Cavalli-Sforza; of the Hadza tribe in East Africa pursued by a team from University College London; of the Tongariki Islanders on the New Hebrides and the Thule Eskimos of Greenland. It also provided support to a Canadian team for an immuno-epidemiological and genetic study of the population of Easter Island before the establishment of an international airport was

44. Neel, James V. to Lowry, R. Lowry, 31 May 1962. WHO Archives. File G 3/522/4. WHO Scientific Group on Research in Populations of Unusual Genetic Interest.

45. Neel, n. 26, p. 129.

46. Neel, James V., Salzano, Francisco M.; Junqueira, P. C. et al. Studies on the Xavante Indians of the Brazilian Mato Groso. American Journal of Human Genetics. 1964; 16: 52-140; Research in population genetics of primitive groups. World Health Organization Technical Report Series, no. 279. Geneva: World Health Organization; 1964. Online: http://whqlibdoc.who.int/trs/ WHO_TRS_279.pdf. Neel has written extensively about his studies in Brazil and Venezuela in his autobiography; Neel, n. 26. Shortly after his death, his studies of the Yanomama Indians and his handling of the measles epidemic in the tribe came under ethical scrutiny but his Brazilian colleagues as well as historians have rallied to his defense, even if recognizing the institutional shortcomings of anthropological research more generally; see Salzano, Francisco M.; Hurtado, Magdalena, eds. Lost paradises and the ethics of research and publication. Oxford: Oxford University Press; 2004. For an interview with Salzano and his work on the American Indians, including his collaboration with Neel, see online: http://revistapesquisa.fapesp.br/ en/2006/10/01/a-geneticist-of-polemic-opinions/ (accessed 6 Jul 2013). On changing ethical frameworks for research on indigenous people in Brazil, Ventura Santos, Ricardo. Indigenous peoples, bioanthropological research, and ethics in Brazil. Issues in participation and consent. In: Ellison, George T. H.; Goodman, Alan H., eds. The nature of difference. Science, society and human biology. Boca Raton: Taylor \& Francis; 2006, p. 181-202. 
to put «an end to the opportunity for study of this comparatively isolated group» ${ }^{47}$.

Not everyone at the WHO was convinced of the appropriateness of the studies. Assistant Director-General, Dr. John Karefa-Smart from Sierra Leone, in particular, expressed his strong objection against this kind of «anthropological excursions» in view of other «urgent priorities» in Africa and elsewhere. Other officers agreed that the study would help genetic research rather than public health issues in Africa ${ }^{48}$. In response the promoters always again pointed to the urgency of collecting all possible information on the quickly vanishing populations that offered the possibility to study the deep history of humanity and understand the evolutionary pressures and breeding patterns that have determined the «genetic attributes of civilized man» ${ }^{49}$.

The genetic study of human populations fitted with a broader scientific, political and ideological focus on «populations» at the time. Population had been a central area of scientific and political preoccupations since the 1920s. The principles of population genetics were formulated in that time and the health and reproduction of human populations became a central concern of national policies. The League of Nations and other international institutions, too, made «populations» the focal point of their interventions in regard to issues of migration, demography, land use, colonial expansion, and military conflict. These trends persisted in the postwar era, under changed technical and political constellations. National government and new international institutions like the UN and its various agencies continued to regard a population-based approach as central to issues of development, migration, health, reproduction, education, food security, conflict resolution, rights, and equality in an era of decolonialization, Cold War tensions, global dependencies, and new technical capabilities ${ }^{50}$.

47. Director, Health Promotion and Protection (WHO) to Regional Director, Western Pacific Regional Office, 13 February 1964. WHO Archives. File G3-370-2. Plan for a medical research program related to human genetics (1959-65).

48. Karefa-Smart, John (WHO Assistant Director- General) to Deputy Director General. Memorandum, 31 October 1966 (with accompanying handwritten notes). WHO Archives. File G3/18/20. Grant to Istituto di Genetica, Università di Pavia, Italy, in respect of population genetic studies of the Babinga pygmies.

49. Neel; Salzano; Junqueira et al., n. 46, p. 52-140 (52).

50. Bashford, Alison. Population, geopolitics, and international organizations in the mid-twentieth century. Journal of World History. 2008; 19: 327-347; Bangham, Jenny; de Chadarevian, Soraya. Human heredity after 1945. Moving populations centre stage. Studies in History and Philosophy of Biological and Biomedical Sciences. 2014; 47: 45-49. 
«Primitive populations» specifically had long been at the center of debate in conservationist circles. The debate was fuelled by the question, first formulated in the 1910s, if "primitive people» belonged to «nature» and for this reason should be protected like fauna and flora or if, on the contrary, they needed to be excluded from the nature parks that were being created. A question cutting across this alternative was whether «primitive people» held customary rights in the area they inhabited and for that reason could not be dispelled from their territory. In the postwar era this debate continued between proponents of the idea of «anthropological reserves» and those who countered that overpopulation of indigenous people in the protected areas would pose a threat to the natural environment. The concerns led to the eviction of indigenous people from conservation areas at a time when anthropologists and geneticists were, at least rhetorically, engaged in a race with time to salvage what information could still be gained from the «vanishing» populations ${ }^{51}$. UNESCO was among the international agencies participating in these debates-as in related discussions about the meanings of «race». In the 1970s the question of the status of indigenous people moved more decidedly from a conservationist debate to a legal discourse of human rights while in the context of the emerging environmental movement indigenous people were held up as an example for living in a harmonious balance with nature ${ }^{52}$.

In the mid-1960s the study of primitive people pursued under the aegis of the WHO gained new impetus through the collaboration with the International Biological Program (IBP). The seven-year program sponsored by the International Council of Scientific Unions and supported by around fifty countries provided a framework for the study of biological productivity and environmental change. The studies of «primitive populations» found place under the heading of «human adaptability studies». At a preparatory meeting for the WHO/IBP combined project, Neel, together with Salzano, his collaborator in the population studies in Brazil, once more succinctly summarized the main research interests guiding the study of «primitive people». These were, firstly, the question of the genetic divergence of human populations and the tempo of human evolution; secondly, the study of biological parameters of people in the «pre-Columbian state»;

51. Radin, Joanna. Latent life. Concepts and practices of tissue preservation in the International Biological Program. Social Studies of Science. 2013; 43: 483-508.

52. De Bont, n. 39. 


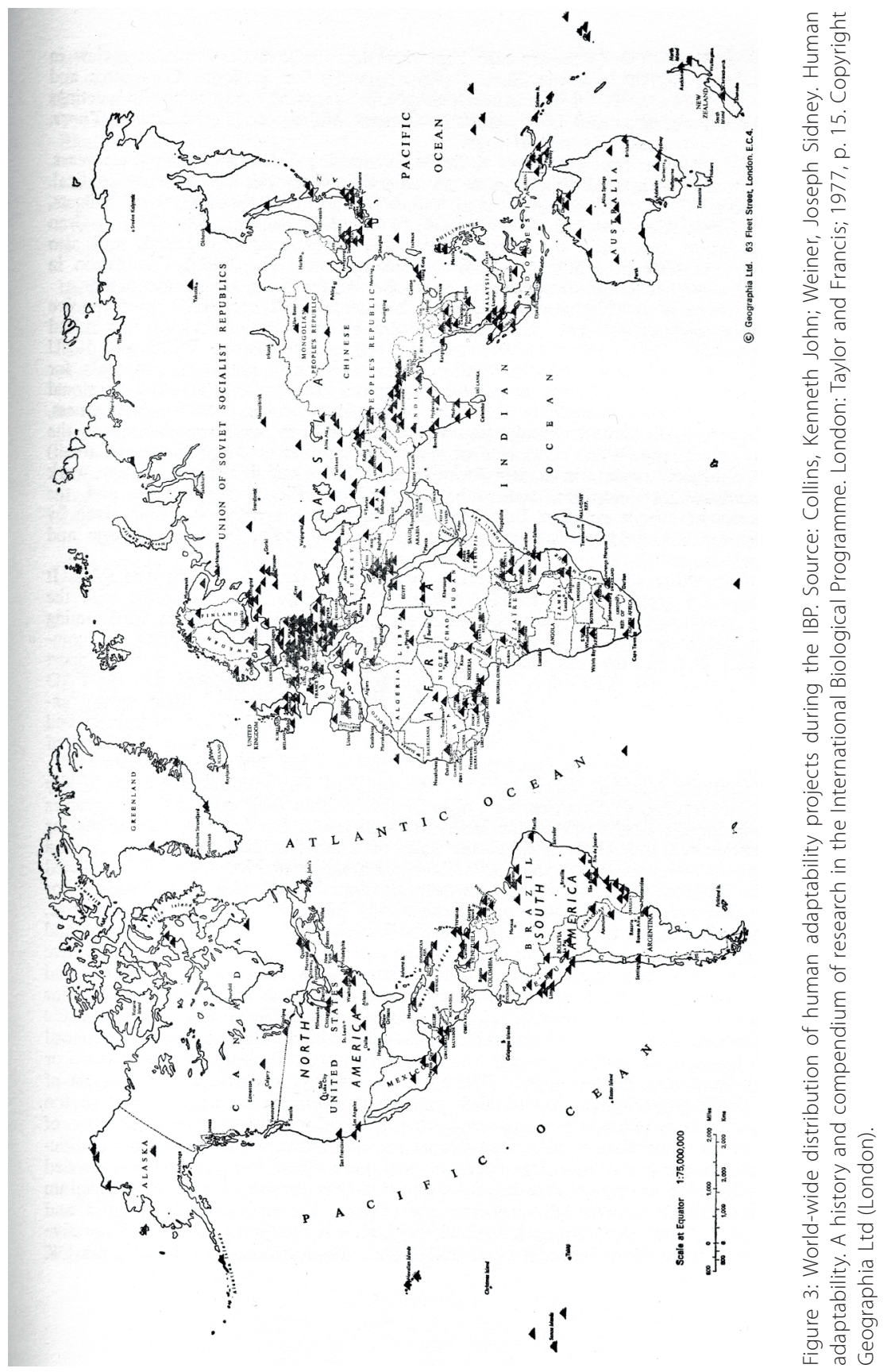


and, thirdly, the study of disease patterns «when these primitive groups make the transition from near-Stone Age to an Atomic Age existence». As the two researchers explained, in final analysis the study of «primitive people» would help understand the evolution of current populations ${ }^{53}$. An updated field guide integrated findings and experiences of the ongoing studies. It also included a long list of populations deemed «suitable» for study ${ }^{54}$. Under the aegis of the IBP the study of primitive people expanded considerably $^{55}$ (figure 3).

\section{International legitimization and standard procedures}

Stevenson and Neel responded to a call of the WHO to draw up a list of possible projects for the organization's new program in genetic research. Others wrote to the WHO unsolicited. What support did they expect from the WHO? And how did the support of the WHO shape their projects?

Scientists were quite explicit in respect to what they expected to gain from the support of the WHO. On top of the list we find the legitimization WHO support was expected to provide. For instance, when Neel asked the WHO for «some official recognition» of his pilot study of the Xavante Indians, the «official status» such a sanction would provide to himself and the Brazilian members of the team was foremost in his mind. International recognition of the study «would strengthen the hands of the Brazilians in turning to their Air Force for the necessary transportation and the Indian government service for the necessary cooperation». Regarding his own position Neel regarded it as «helpful to go on temporary active duty with WHO, not for financial reasons but because of the international status

53. Neel, James V.; Salzano, Francisco M. A prospectus for genetic studies on the American Indians. In: Baker, Paul T.; Weiner, John S., eds. The biology of human adaptability. Oxford: Clarendon Press; 1966 (246).

54. Research on human population genetics. Report of a WHO scientific group. World Health Organization Technical Report Series, no 387. Geneva: World Health Organization; 1968. Online: http://whqlibdoc.who.int/trs/WHO_TRS_387.pdf; accessed 21 May 2012.

55. Collins, Kenneth John; Weiner, John Sidney. Human adaptability. A history and compendium of research in the International Biological Programme. London: Taylor and Francis; 1977. 
implied» ${ }^{56}$. Legitimization and international standing, then, were one important reason for scientists to engage with the WHO.

There was more, according to Neel (to stay with this example), the WHO could do to assist the study of primitive people on a larger scale. It could explore the possibility of assisting appropriate groups of specialists to launch pilot projects and of locating support for full scale studies; it could alert governments about the urgency of such studies; it could provide assistance to enable data analysis; facilitate collaboration with other international agencies; provide fellowships and training grants to encourage exchange and provide theoretical and practical instruction in cooperative and interdisciplinary studies; organize meetings for the exchange and pooling of information; assist with the development and standardization of procedures and the wide dissemination of results ${ }^{57}$.

Neel's expeditions took him to some of the most remote areas of the Amazon and the territory of the people he and other scientists were tracking often straddled national borders. This made logistic and administrative support by the WHO particularly useful. Yet other projects supported by the WHO were equally complex and required the coordination of international and interdisciplinary teams of researchers, the engagement of local governments, logistical support on many levels, and the management of large data sets. How then did the WHO respond to this barrage of expectations? Turning the question around we can also ask: what kind of support did the WHO provide to encourage transnational projects or research projects that had a global reach and thus fitted its mission as a world organization?

As all UN agencies, the WHO was a complex organization that acted on three interlocking levels: on the level of member states, institutionalized in the World Health Assembly, that negotiated programs and budgets; of the Secretariat, composed of civil servants, drawn from various countries, who executed the program; and a series of consultative NGOs, advisory committees, and international experts ${ }^{58}$. Leaving these complex levels of decision making and responsibility aside, we can say that the WHO mostly supplied infrastructural support on which transnational scientific studies

56. Neel, James V. to Lowry, R. Lowry, 27 December 1961. WHO Archives. File G 3/445/3. Human genetics - study of primitive tribes in Brazil.

57. Research in population genetics, n. 46, p. 25-26.

58. Selcer, n. 2, p. 20. 
crucially depended. Through its regional offices it facilitated contacts to local government and ministries. The program officers helped with the formation of expert teams that included representatives of the countries where the studies were planned. At its headquarters in Geneva it provided forums for the exchange of ideas and technical knowledge.

Special effort was invested into the standardization of procedures and terminology. This was achieved through the organization of expert advisory meetings and the publication of technical reports that provided comprehensive guidelines for research in particular areas. These widely distributed reports included introductions to research methods and detailed instructions for how to collect, record and analyze data, complete with standardized data entry forms to increase comparability ${ }^{59}$.

As part of the same standardizing effort the WHO created a series of International reference laboratories for specific analyses. For the human population studies were relevant the Reference Laboratory for Abnormal Haemoglobins in Cambridge (UK), for Blood Groups in London, and for Abnormal Chromosomes in Respect to Populations in Edinburgh. Arguably even more fundamental was the support of the WHO in setting up multipurpose banks of frozen blood samples that could cater to current and future users. Detailed instructions of how to collect, preserve, label and transport the samples helped transform «fleshy substrates of variable human bodies» into standardized yet flexible research material that could be used by laboratories around the world ${ }^{60}$. Standardization was a crucial step to achieve comparable results. In many respects standardization was the practical face of transnational or global science.

WHO also organized training courses in specific techniques, as for example advanced courses in the use of computers in human genetics research. Usually these courses took place in host institutions. Moreover, it helped disseminating research findings through its various publication organs, including for instance the Bulletin of the World Health Organization.

Last but not least, the WHO provided financial support for individual research projects, although the sums were often rather modest. For instance,

59. The standardization of terminologies, methods and procedures was a general aim of the WHO; for an example in the diagnostic field and its complex implications. Gradmann, Christoph. Sensitive matters. The World Health Organisation and antibiotic resistance testing, 1945-1975. Social History of Medicine. 2013; 26: 355-374.

60. Radin, n. 2. 
the MRC received \$ 12,000 to compensate for expenses incurred in connection with the comparative birth study in Stevenson's unit (it mostly covered travel and data collection and processing), and Cavalli-Sforza received first $\$$ 5,000 , and then another $\$ 2,000$, for his studies of the Babinga pygmies (the figures should be multiplied by 7 for a rough guide to today's value). This included provisions for medical services for the participants in the study.

Scientists stood to gain from such interventions. They regarded the WHO as an «ideal frame» in which international cooperative studies could be conducted ${ }^{61}$. It is unlikely that the comparative birth study or the worldwide study of «primitive populations» could have proceeded without the support of international agencies like the WHO or, later, the IBP that offered similar infrastructural support.

\section{Conclusions}

This essay suggests that the WHO was a significant player in human heredity studies after WWII. Although research was not its main mission, the agency stimulated large scale research projects in human heredity and encouraged governments to step up their efforts in this field of research because of the significant public health issues it presented and because so little was known about the genetic structure of human populations. World-wide medicoanthropological, genetic and demographic studies of human populations suited the WHO's international agenda and a more general political focus on populations. Through its support of large scale cooperative projects the WHO encouraged life scientists to think on a larger scale ${ }^{62}$. Engaging with the projects supported by the WHO offers the opportunity to direct our investigations to broader political questions underpinning research

61. Sheba, Chaim. Draft proposal [for a Mediterranean Club for Human Population Genetics]; attached to letter Sheba, Chaim to Dobson, R. Lowry, [27?] Oct 1961. WHO Archives. File G3-370-2. Plan for a medical research program related to human genetics (1959-65). The plan for a «Mediterranean Club» was launched by Sheba from the Tel-Hashomer Government Hospital in Israel, and included France, Italy, Greece and Turkey but no Arab country. From the records I consulted it is not clear if WHO support materialized.

62. On the role of international organization, especially the IBP, in stimulating big data projects in the life sciences Aronova, Elena; Baker, Karen S.; Oreskes, Naomi. Big science and big data in biology. From the International Geophysical Year through the International Biological Program to the Long-Term Ecological Research (LTER) network, 1957-present. Historical Studies in the Natural Sciences. 2010; 40: 183-224. 
in the life sciences and to consider the place of science and transnational scientific projects in the Cold War context.

Often the studies supported by the WHO relied on the initiative of single individuals or small interdisciplinary teams of scientists with institutional affiliations in industrialized countries with significant research capabilities like the US or Britain in the cases presented here. Yet using their links to the WHO and piggybacking their projects on existing WHO programs, scientists gained a larger stage and international legitimization for their work. They also drew local elites on whose support they relied into the international science arena. Acting on a global level, the WHO promoted cooperative international projects, facilitating the formation of international and multi-disciplinary teams and providing technical and infrastructural support on many levels. At the same time, especially through its regional offices, it helped negotiating contacts with national governments and local authorities. In this respect it is perhaps possible to view the WHO, and especially its regional offices, as a late twentieth-century version of the go-between described in The Brokered World edited by Simon Schaffer, Lissa Roberts, Kapil Raj and James Delburgo for the period around 1800. In their introduction to the book the editors indicate that the increased volume of mediations and exchange led to the emergence of new kinds of institutions that aimed «to render permanent and powerful the work of translation, accumulation and analysis» ${ }^{63}$. Through its various activities of mediation between different actors the WHO shaped research agendas and created policies and alliances in ways that are typical for the role of go-betweens ${ }^{64}$. The place and meaning of the population studies in the local, national and regional context in which they were carried out will require more historical attention ${ }^{65}$.

63. Schaffer, Simon; Roberts, Lissa; Raj, Kapil; Delbourgo, James, eds. The brokered world. Go-betweens and global intelligence, 1770-1820. Sagamore Beach, MA: Watson Publishing International; 2009 (p. xxxvii). For a similar suggestion that institutions can serve as «cultural brokers» see Schumaker, Lyn. Africanizing anthropology. Fieldwork, networks, and the making of cultural knowledge in Central Africa. Durham and London: Duke University Press; 2001.

64. The figure of the go-between is here detached from the colonial context in which it has mainly been studied to date but to which it is not necessarily bound. I thank Kapil Raj for a discussion of this point.

65. For an example, Anderson, Warwick. The collectors of lost souls. Turning Kuru scientists into whitemen. Baltimore: John Hopkins University Press; 2008. Carleton Gajdusek, whose expeditions to New Guinea are at the center of Anderson's account, was on the WHO Scientific Group on Human Population Genetics. On the interplay between the medical and genetic study of 
The designation of the indigenous populations studied under the aegis of the WHO and the IBP as «primitive» re-iterated colonial attitudes that prefigured the status of the people as passive objects of research rather than participants in the studies. Such an understanding of indigenous people was inherent in the postwar discourse of development espoused by the WHO but at the same time stood in tension to the efforts of decolonizing nations to overcome the imperial legacies that also found a voice at the $\mathrm{WHO}^{66}$. Nevertheless, the scientists engaged in the population studies drew a clear distinction between the «old-fashioned and static subject of physical anthropology» as practiced in the preceding decades and the «ecologically and genetically based» approach to human population studies that informed their investigations ${ }^{67}$. Unlike in earlier anthropological expeditions the provision of medical service also was an integral part of the studies conducted under the aegis of the WHO.

The population studies of the 1950s to the 1970s played a pivotal role in the development of postwar human and medical genetics, not least by setting a research agenda that continues to be pursued under changed technical and political conditions. A lasting legacy of these efforts are the sample collections, including especially the vast blood collections that are still kept in freezers around the world ${ }^{68}$. Genomic technologies are offering new ways to analyze the frozen samples and tease out new information. In the 1990s scientists tried to add to the sample collections by launching the Human Genome Diversity Project (HGDP). The project was directed by Cavalli-Sforza, by then Professor of Genetics at Stanford, whose first

indigenous populations, a modernizing national movement and international health programs in Mexico in the 1960s see Suárez-Díaz, Edna. Indigenous populations in Mexico. Medical anthropology in the work of Ruben Lisker in the 1960s. Studies in History and Philosophy of Biological and Biomedical Sciences. 2014; 47 Part A: 108-117. For an expansion of this analysis to more recent genetic studies in Mexico and other South American countries see Wade, Peter; López Beltrán, Carlos; Restrepo, Eduardo; Ventura Santos, Ricardo, eds. Mestizo genomics. Race mixture, nation, and science in Latin America. Durham and London: Duke University Press; 2014.

66. On the contradictions that shaped the «race question» in the development of UN organizations and the centrality of the question in the UN's intellectual genealogy see Amrith, Sunil; Sluga, Glenda. New histories of the United Nations. Journal of World History. 2008; 19: 251-274 (257).

67. Collins; Weiner, n. 55, p. 2. On postwar changes in anthropological research practices see also Lindee, Susan; Ventura Santos, Ricardo. The biological anthropology of living human populations. World histories, national styles, and international networks. An introduction to supplement 5. Current Anthropology. 2012; 53 (suppl. 5): S3-S16.

68. Radin, n. 51; Radin, n. 2. 
genetic expeditions to Africa in the 1960s had received support from the WHO. The HGDP followed a similar agenda and employed much the same rhetoric of urgency as the earlier population studies ${ }^{69}$. As in these earlier studies sampling proceeded by linguistically defined populations rather than on a grid based on geographical distances as had also been proposed. However, the study was highly contested from the beginning and eventually floundered. Among those who protested the HGDP were the indigenous people included in the study who reacted against the suggestion that they were vanishing isolates of historical interest. They also opposed the scientific exploitation of their genetic heritage ${ }^{70}$. These struggles continue in the age of bioprospecting and pharmacogenomics that mark the transition from Cold War internationalism to postcolonial structures of globalization. A significant development in this context is the current elaboration of new protocols for the use of old and new human tissue samples that better respect the sensibilities, rights and needs of the indigenous people participating in genetic studies ${ }^{71}$. Responding to these demands, also the WHO has developed new ethical guidelines for research involving indigenous people. They build on the principle that research must be «beneficial and acceptable to both parties» and that this can only be achieved through participation on all levels of the research process and through sharing of the results ${ }^{72}$.

Equally significant perhaps, in the wake of the human genome project, -often hailed as an international effort, although effectively led by the US and Britain - many developing nations have put significant resources into building up their own genomic surveys of their populations. These developments mark the changed technical, socio-political and economic conditions in which human population studies are conducted and find their meaning.

\footnotetext{
69. Ventura Santos, n. 40.

70. Reardon, Jenny. Race to the finish. Identity and governance in the age of genomics. Princeton: Princeton University Press; 2004; M'Charek, Amade. The human genome diversity project. An ethnography of scientific practice. Cambridge: Cambridge University Press; 2005.

71. Kowal, Emma. Orphan DNA. Indigenous samples, ethical biovalue and postcolonial science. Social Studies of Science. 2013; 43: 577-97; Kowal, Emma; Radin, Joanna. Indigenous biospecimen collections and the cryopolitics of frozen life. Journal of Sociology. 2015; 51: 63-80.

72. World Health Organization. Indigenous people and participatory health research [undated]. Online: http://www.who.int/ethics/indigenous_peoples/en/index6.html; accessed 3 Aug 2014.
} 


\section{Acknowledgements}

I would like to thank Ana Barahona, Gisela Mateos and Edna SuárezDíaz for putting together this special issue as well as for organizing the session on Transnational science during the Cold War at the meeting of the International Society for the History, Philosophy and Social Studies of Science in Montpellier in July 2013, where a first version of this paper was presented. For incisive comments and generous feedback I also thank John Krige, Jean-Paul Gaudillière, Kapil Raj and two anonymous reviewers. 